\title{
An Economic Exploration of Mining Industry of Northern Minnesota
}

\author{
By Undralsaikhan Dambii \\ Mentor: Rubana Mahjabeen
}

\begin{abstract}
Iron ore minining industry plays a big role in northern Minnesota. It contributes around 30 percent of the regional GDP. In recent time many of these regional mining companies are laying off their employees. China is one of the largest economies of the world. As such it has great impact on world's economy. This exploratory study investigates if there is some connection between Chinese economic slowdown and regional mining layoffs. For this purpose this paper uses relevant news articles, academic papers, expert interviews and data from various secondary sources. According to the findings of this study multiple factors including slowdown of Chinese economy, steel dumping by China, rising world production of iron ore, low U.S. domestic demand of iron ore, low iron ore price, and, natural resource boombust cycle can be utilized in explaining these regional mining layoffs.
\end{abstract}




\section{Introduction}

Iron ore minining industry plays a big role in northern Minnesota. It contributes around 30 percent of the regional GDP (Ongaro, 2016). In recent time many regional mining companies of Minnesota have been laying off their employees. In order to search for reasons of these layoffs attention should be given to a number of factors including foreign economies, especially, Chinese economy. Compared to last three decades of enormous growth, Chinese GDP growth has slowed down in recent years. From two-digit growth rate it went down to 6\% (The World Bank, 2016b). This might have some impact on the United States economy, specifically on Minnesota. China's demand for steel and raw materials dropped significantly as the nation's economic growth slowed down. At this same time over a thousand people lost their jobs in mining sector in Minnesota (Myers, January 2016). The goal of this study is to find out the impact of Chinese economy on regional economy and mining industry of Minnesota. This research explores answers to following questions: how does Chinese economy impact regional industries in Minnesota and how do the layoffs in mining industries affect regional economy?

This paper is structured in the following way: literature review, research methodology, newspaper articles, expert interviews, data analysis, and, conclusion.

\section{Literature Review}

Literature review includes peer reviewed academic research papers on mining and economic growth of China and U.S mining. Literature review builds an understanding of the issues related to iron ore industry as well as explains how natural recourse-based economy behaves.

Since last century China has experienced major economic growth. There are different factors that influenced this big jump. According to Zhu (2012), the development of China can be divided into several time intervals that can explain main factors of their economic improvement. After being stagnant for centuries China started experiencing growth since 1950s more steadily. In early 1950's China established People's Republic and started industrialization. The government started investing heavily in steel, concrete, and heavy machinery. The source of this investment came from agricultural sector, it was achieved by restricting consumption and keeping the prices of agricultural produce artificially low. At that time growth rate of China was around 3\%. During 1952-1978 China was more concentrated on capital accumulation, both human and physical. In the late 1970s, China started experiencing more growth. The government started implementing gradual decentralization in hope of improving aggregate economic output and standard of living. During this time shift of workers from farms to non-agricultural sector played a big role in boosting the economy. During 1997-2007 some stateowned enterprises were allowed to be privatized. In 2001 China joined World Trade Organization (WTO), cutting off tariffs and becoming foreign trade friendly. 
Combined with privatization and trade liberalization Chinese economy experienced growth in both state and non-state sectors. Between 1998 and 2007, Total Factor Productivity were 5.50 (state sector) and 3.67 (non-state sector) (Zhu, 2012).

Study by Jefferson et al. (2006) supported these findings. Technological advances helped China to grow faster; moreover, access to WTO in 2001 spurred the growth by giving an access to the foreign direct investment (FDI) and more investment in $\mathrm{R} \& \mathrm{D}$ sector. China made a shift in reallocating labor and making the rural sector more efficient. However, authors cautioned that it was not certain if China could keep growing at the same rate in the future. (Jefferson, $\mathrm{Hu}, \mathrm{Su}$, Bosworth, \& Ranis, 2006).

Wang et al. (2014) explored mineral resource carrying capacity (MRCC) of 21 mining cities of China. Chinese economy has 262 resource-based cities. Till 2012, mining cities have supplied 52.9 billion tons of coal, 5.5 billion tons of oil, and 5.8 billion tons of iron. Mineral resources are the crucial part of Chinese economy, with its growth China became the number one country in the world with its mineral resources consumption. MRCC index involves index of economy measured by economies of scale and contribution to GDP, index of society dimension measured by the job creation, index of potential dimension measured by guarantee period of the assurance life of mineral resources, and environmental pollutant emissions. The research concluded the following: First, that MRCC is stronger in the central, western mining cities and growing mining cities, which have great potential for mining industry. Second, mining development in growing and mature mining cities are relatively stable or better, they have the higher contribution to employment and economy; the regenerating mining cities' economies of scale and guarantee period are in good place due to better industry transition. Third, there is a contradiction between the mineral resources exploitation and the environment in many mining cities, especially for the western mining cities and their growth (Wang, Zhu, \& Xiong, 2014).

In any country mines are usually located in rural areas, making them a good source of income for the local residents. International researches and papers tend to have different and sometimes contradicting opinions on mining as a key for development. There are few research on mining and economic growth in the U.S. Deller and Schreiber (2012) explored the impact of mining on rural areas in the U.S from 2000 to 2007 time period. The authors used employment to population ratio and share of total employment in mining in their computation. The results from the research show that higher levels of mining employment are connected with lower population growth and higher levels of income growth. Also, higher mining employment has no influence on overall employment growth. Findings suggest that mining might not provide more jobs to locals, but provides an alternative better paying job compared to other jobs in the region. Mining jobs sometimes might be seasonal, and the case studies show that workers might be prepared and use more savings in times of unemployment. This paper has some limitations, such as a short time observation of 
7 years, which does not capture the whole cycle of boom and bust (Deller and Schreiber, 2012).

Metal use and supply has grown significantly over the years due to urbanization and globalization. Weidmann et al. (2014) compared material footprint of metal ores to the GDP of countries to find how much economic benefit countries achieve per unit of metal footprint. In 2008, world metal ore extraction reached 7.4 billion tons mark. Because infrastructures are highly dependent on iron ore the number is expected to grow in the future. After 2000, rapid development of China and other developing countries has increased demand for iron ore dramatically leading to the global price of iron ore to steadily increase. Moreover, development strategy put pressure on countries to keep up with production of metals in order to keep up with the development rate. This shows that iron ore production needs to become more efficient. This paper measures efficiency of production using gross domestic product (GDP) over domestic material consumption (DMC). The material footprint (MF) is a consumption-based material flow indicator. Resource productivity can be found in the following way: $\mathrm{P}_{\text {cons }}=\mathrm{GDP} / \mathrm{MF}_{\mathrm{mo}}$. The results show that in 2008 the extraction

and raw material embodied in exports (RMEEX) was in hand of top 5 producing countries: Australia, China, Brazil, India, and, Guinea, which accounted for $80 \%$ of world production of iron ore. This research showed that the wealthier a country becomes the more it consumes iron ore. However, on a global level, efficiency in production of iron ore has not increased (Weidmann, Schandl, \& Moran, 2014).

\section{Research Methodology}

To answer research questions this paper utilizes following three sources. First, information from various news articles on U.S mining and the economic impacts of Chinese iron ore on the U.S economy. Second, findings from interviews of regional iron ore professionals on topic of iron ore industry in northeast Minnesota. Through interview of experts the paper acquires more insight into the reasons of recent layoffs and overall picture of the regional economy as well as the industry itself. Third, data from various reputed sources on iron ore and Chinese economy.

\section{Research Findings}

\section{Newspaper Articles}

According to Minnesota Department of Natural Resources (MN DNR, 2016), Minnesota is one of the biggest producers of iron ore and taconite in the U.S. Taconite is a lower quality iron ore, mined using high technology. The taconite is crushed and turned into small sized pellets. Those are melted and blown by oxygen to make steel. Now iron ore is mined only in Mesabi Range of Minnesota. 
Dan Kraker (April 11, 2016) reported that in 1980s over 10,000 mine workers lost their jobs in the Iron Range. As a result, Iron Range Resources and Rehabilitation Board (IRRRB) and the local governors invested around $\$ 3$ million dollars to build a factory for chopsticks to export to Japan. However, within 2 years the factory was closed. This is an example of how the region tried to diversify the economy and failed. During 2015 about 2,000 workers were laid off in mining sector not including hundreds or thousands of workers who have been relying on mining. This is the result of some illegal steel dumping by foreign countries. In order to be competitive the U.S had to lay off some workers and close 11 mines. It is uncertain when the mining economy will start booming again. However, some companies like Cliffs Natural Resources are expecting to open new mine.

Andrew Krueger (June 9, 2016) reported that Cliffs Natural Resources has announced to move up the United Taconite reopening from October 2016 to August 2016. This is due to the new 10-year deal with ArcelorMittal USA and higher demand from other companies as well. United Taconite recently laid off around 450 employees but expecting to bring them back in August 2016. As demand for pellets is increasing, it gives another chance to the closed mines in Minnesota. Cliffs CEO Lourenco Goncalves said that the United States crisis of steel and iron ore is behind now.

Another earlier news by John Myers (January 8, 2016) reported similar mind set of Essar Steel Minnesota LLC (ESML). ESML laid off several employees due to the slowdown of construction in Nishwauk, Minnesota. ESML said that the layoffs were temporary due to the short of cash in their massive project. In 2008 there was a promise to build a new fullscale taconite iron ore operation in Minnesota. Essar received $\$ 850$ million in 2014 for construction and said to contribute more of its own money - in order to start producing taconite pellets in 2016. Due to the hard time in the industry it has been hard to find enough money to continue the construction. A more recent news by Myers (July 8, 2016) reported that ESML has filed for bankruptcy and Minnesota has turned its focus on Cliffs Natural Resources.

According to Kraker (April 11, 2016) some people take the downturn in mining as a signal to start diversifying the regional economy and open new businesses that can prevent the economy to get hit strong when mining is not doing well. Sertich of IRRRB says that, it is going to be hard to replace an industry that has been paying this good and had that of a big impact on the regional economy. There are many failure stories like a chopstick factory trying to diversify Iron Range economy, but there are also some success stories. Minnesota Twist Drill of Chisholm, Minnesota is one of the few companies in the U.S that manufactures drill bits. The company started in 1960s and supplies drill bits not only locally but also globally. It has grown in past few years and now makes \$22 million in sales. They provide jobs with high salaries and don't get affected by the mining downturns. Like Minnesota Twist Drill there are several other companies that are not based on mining but still provide jobs and money for the local economy.

News article by Jasmine $\mathrm{Ng}$ (January 12, 2016) informed that even though import of iron ore by China has experienced ups and downs, overall it has an upward trend. In January 
2016 Chinese imports of iron ore was at an all-time high. In 2015 China imported 952.72 million tons of iron ore. As price of iron ore has been very low China was able to purchase and use iron ore for increasing amount of steel production and exports. Also, lower iron ore price made major iron ore producers like, Australia and Brazil work toward in increasing their market share in China.

Don Davis (February 22, 2016) reported that President Barack Obama announced to protect American economy from Chinese cheap steel dumping that costed 12,000 workers their jobs and 2,000 in Minnesota alone. President said Chinese steel imports would not end but at least there would be some fairness. In recent years China's economy has been slowing down and demand for steel has been declining. China is selling steel at highly subsidized rates to the U.S instead of cutting production. To fight it Minnesota Governor Mark Dayton and Minnesota congressional delegation have asked Obama to take actions against Chinese steel subsidization.

Myers (May 18, 2016) reported that the U.S. is ready to impose $266 \%$ tariff on cold rolled steel from China and 77 percent tariff on cold rolled steel from Japan. Both countries are accused of selling steel below the market price in order to keep their mines operating. Alan Tovey (May 18, 2016) reported that U.S. will impose 522\% import tariff on Chinese steel $-266 \%$ anti-dumping levy and $256 \%$ anti-subsidy duty. The U.S. Commerce Department said tariffs helped to increase Chinese steel price by 500 percent, which totaled to $\$ 272.3$ million in 2015. The United States International Trade Commission (USITC) rulings on China and Japan cold-rolled steel duties came in late June of 2016 (USITC News Release, June 22, 2016). For China it has been tempting to use dumping to solve their short term problems, but the U.S has made it clear that it is not going to be that easy.

\section{Expert Interviews}

Two specialists of mining industry were interviewed by the author of this paper in June 2016 (Ongaro, 2016; Johnson, 2016). Frank Ongaro is executive director of Mining Minnesota. Mining Minnesota works with locals, organizations, and businesses to create more jobs in mining sector through responsible development of natural resources. Ongaro has been on this position since 2006. From 2001 to 2006, he served as president of the Iron Mining Association of Minnesota (IMA). He has been in the industry for a long time and is one of the most informed people in Minnesota about mining. Kelsey Johnson is the current president of Iron Mining Association. IMA works on public policies that affect iron ore mining. This association also collaborates with educational institutions.

Both interviewees are experts on mining of northeast Minnesota and dedicated to improve mining industry in Minnesota. They work with different mining companies and businesses as well as work on regulations and environmental issues. They are wellinformed people who know what is happening right now in the iron mining industry. They discussed about how the world demand affected Minnesota's mining and how it is slowly recovering from the shock. (For interview questions see Appendix.) 
According to Ongaro Minnesota mining industry is struggling but still surviving. People took 100 years of mining in the region for granted. The region is still dependent on mining and mining will be a significant factor for generations to come. Mining accounts for around $30 \%$ of the regional GDP. It does not only provide jobs to people in the mining industry but also to suppliers and vendors of the industry. Ongaro said, "Why replace a pie, when we can grow it?" He implied that mining industry could be grown and have a future to generate more and more money as well as jobs. There is a real opportunity to double benefits in jobs and tax revenue.

Johnson said that there are 11 operating mines in North East Minnesota: 6 are open, 5 are voided and 1 is operational. These mines produce 11 tons of steel annually and contribute 3 billion to the NE Minnesota economy. There are 14,000 jobs within the industry. Johnson added that one mining job provides 1.8 vendor jobs such as trucking and service.

According to Johnson, the top steel producers of the world are China (300 million tons), Australia (300 million tons), and Brazil (180 million tons). The problem is that the domestic production is much lower than that of the international. Also, the U.S pays well and protects environment more compared to some countries, leading to a higher price of steel. While the global price for steel per ton is $\$ 30$, the U.S steel price is $\$ 60$ per ton. The global demand is high for steel, but China is subsidizing it with cheaper products. There are cases of international trade agreement violations by China illegally dumping steel. This basically means China was illegally dropping the price of steel when it started facing slower economic growth. Now U.S. tariffs has risen to $267 \%$ on imported steel from China to level up to the international trade agreement.

When asked about current employment/job situation and layoffs of local mining industries, Ongaro stated that it has been struggling for last couple of months. Laid off workers hurt the economy. It has a "ripple down effect" as not only workers in mining are laid off but also suppliers and vendors like automobile dealership are losing their jobs. As a natural resource based economy Minnesota has seen many cycles and cycles repeat time after time. According to Johnson there are several mines that are not operating right now, which used to employ around 800 people. The industry used to employ 2000 people within mining in 2014 and 2015. It is improving slightly, but not rapidly. Little above 1000 people are expected to be called back and employed with Taconite and Northshore mines.

Both experts stated that many factors worked behind the layoffs. According to Ongaro following are some of those reasons:

- Overall poor performance of domestic economy. So, consumption is down.

- Global economy has slowed down.

- Minnesota's supply of iron ore for steel making is down.

- Subsidized commodities enter the U.S ports from other countries that cost less than what is produced in the U.S, especially from China.

- Sick U.S. mining industry, which makes situation even worse for the region.

- High cost of production in the U.S. 
Johnson stated that the primary reason for layoffs is global sales and forces. Demand for American steel was not high due to higher prices. Even though U.S exports some iron, it faces difficulty selling it. This is mainly due to higher U.S. prices compared to the international market. Moreover, dollar is strong, which makes it harder to sell U.S. iron and other metals oversees. Ten to twenty years ago while it was developing, China used to be a large consumer of U.S steel. Currently, Canada is one of the biggest buyers of U.S steel.

When asked directly if Chinese economy has anything to do with the current situation of the local mining industry Ongaro said, there is a direct correlation. It is part of a steeldumping scenario. As China has been replacing U.S. domestic steel with a much lower priced Chinese steel, the U.S government has filed case against Chinese products. As a result China has to pay high tariffs for their illegal subsidies. Johnson agreed that China has a lot to do. They have 10 times more production capacity than the U.S. Only recently China started pushing the iron market, roughly 2-3 years ago.

To improve current condition and resolve layoffs of local mining industry Ongaro provided various suggestions. First of all, U.S. needs to have right ingredients. The U.S steel price should level up with the world price to be able to compete in the world market. As the margins are low in the U.S it is difficult to be profitable in this business. He said that demand for steel is growing, but the U.S is not using its best capacity. Companies are willing to invest in the industry but prices are dropping for the steel. This does not necessarily mean there are no more companies to come and invest in the region. The demand for steel is still high. Soon Polymet and Anglo Gold mines are to open in the region as well as other companies like Rio Tinto will come to meet the demand. $\mathrm{He}$ added that the reason for high U.S steel price is environmental regulations. It is the model for the world as the U.S follows safety and protects environment as well as does not allow child labor and pay higher wages to workers in mining industry.

Johnson stated that to improve current regional mining condition it is important to make sure that U.S. align with international competitors. Doing an effective job of making sure that the costs are low. Some of the big costs of mining are labor, energy use, documentations, raw material, etc. By keeping production costs low U.S. product can be less expensive and more competitive.

According to Ongaro and Johnson to a person from outside of the mining industry it may seem that the regional economy is facing hard time. However, based on economic reasoning, what is happening right now in the natural resources based economy, is part of a cycle of boom and bust. The local economy fluctuates as the demand or supply of iron ore increases or decreases. The layoffs of the workers in iron ore reflect the decreased demand of the regional iron ore, as the U.S. prices were higher than competitors. This part explains one of the research questions, whether Chinese economic slowdown has any impact on the regional economy. The answer is not solid yes or no, but there are strong impacts of Chinese steel dumping on the U.S. iron ore industry as well as other influencing factors. With prices below the market price, Chinese steel made U.S. steel undesirable in the world market. As a consequence to stay competitive some Minnesota mines had to cut the numbers of their employees or closed temporarily. 


\section{Data Analysis}

This study obtained data on iron ore industry, U.S. mining, and, Chinese economy from various sources, including the World Bank, World Development Indicators (WDI), U.S. Bureau of Labor Statistics, and, U.S. Geological Survey.

In order to find facts on the U.S. mining industry, Quarterly Census of Employment and Wages prepared by the U.S. Bureau of Labor Statistics was obtained. Figure 1 and 2 depict those information.

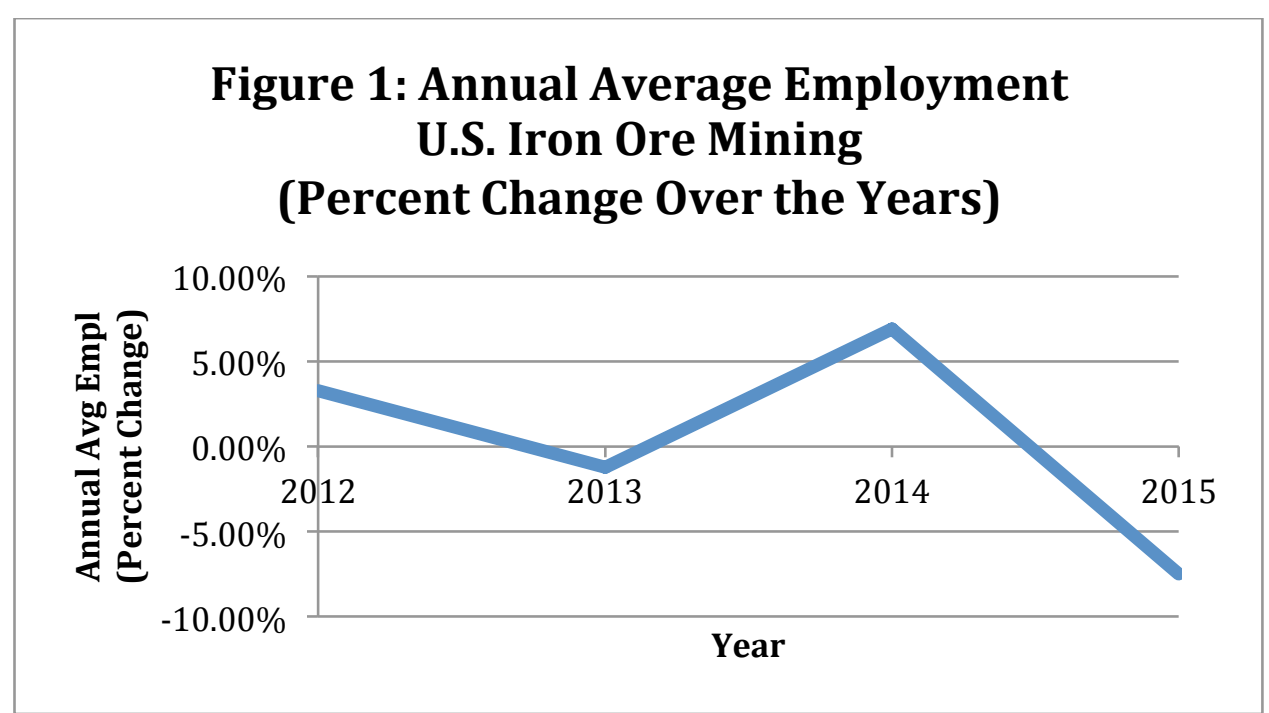

Data Source: U.S. Bureau of Labor Statistics (2016)

Figure 1 shows how much of layoffs can be found in the past few years in the iron ore mining industry. Even though employment in iron ore mining experienced a boost in 2014, it went down sharply almost by 12\% between 2014 and 2015 .

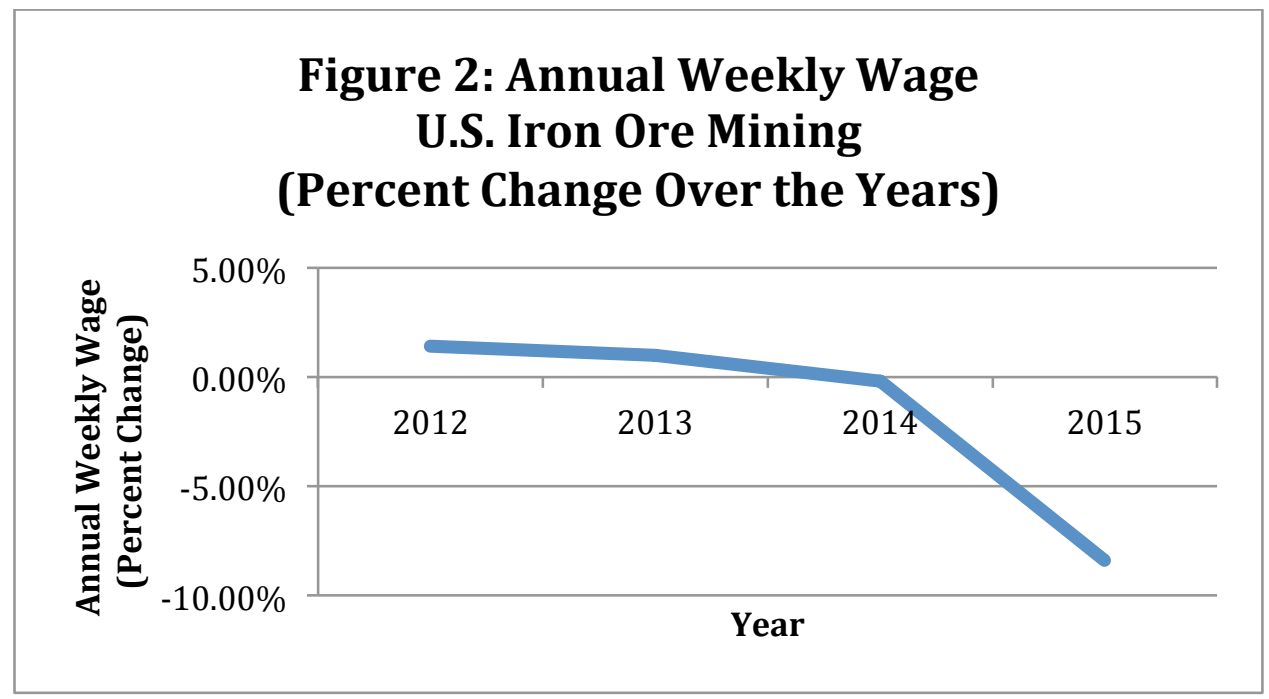

Data Source: U.S. Bureau of Labor Statistics (2016) 
Figure 2 shows that weekly wage has also suffered a downturn in the U.S. mining industry. Further, between 2014 and 2015 annual weekly wage in iron ore mining dropped significantly, almost $8 \%$. These two graphs have captured the current slowdown and layoffs in the U.S. mining industry and thereby of Minnesota regional iron ore mining.

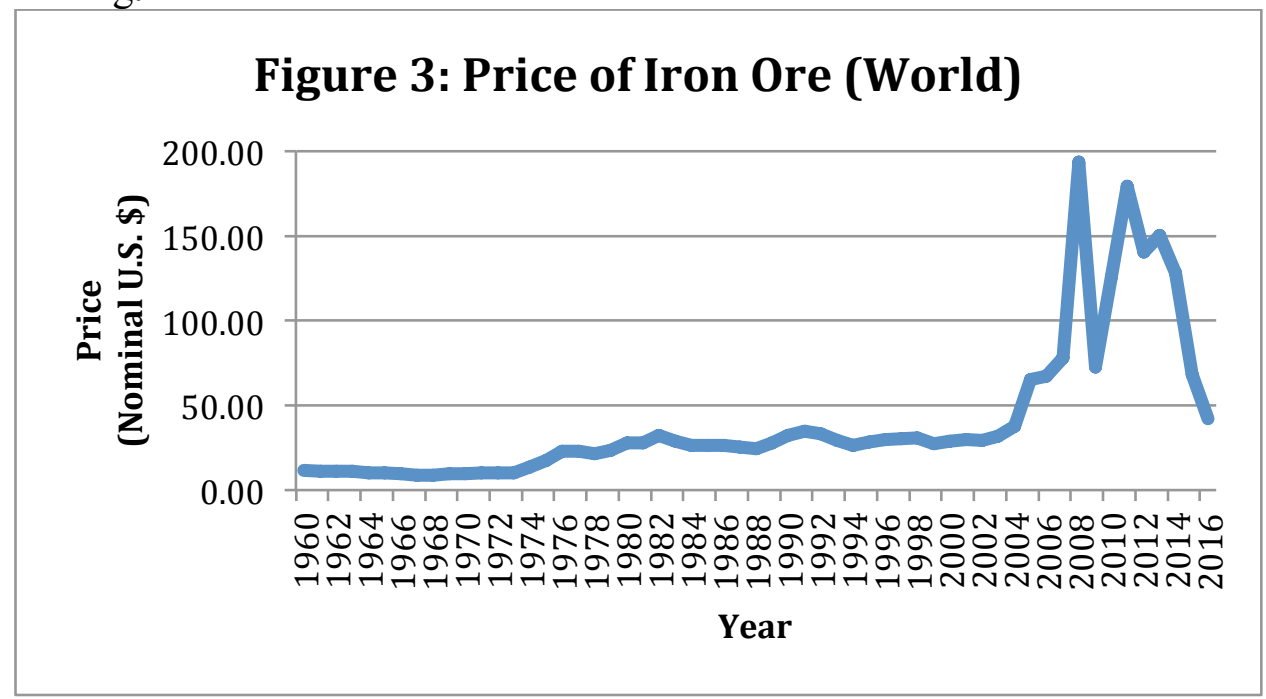

Data Source: The World Bank (2016a)

Figure 3 shows that prices of iron ore were stable until the beginning of 2000s. During recession of 2008 and 2009 prices fell significantly but jumped back high in 2010 and continuously falling since then. From 2010 to 2016 world price of iron ore declined by about $78 \%$. Low price of iron ore provides an indication why wage and employment in iron ore mining industry have fallen. According to economics theory low price of a commodity is the result of either low demand or over supply of that good.

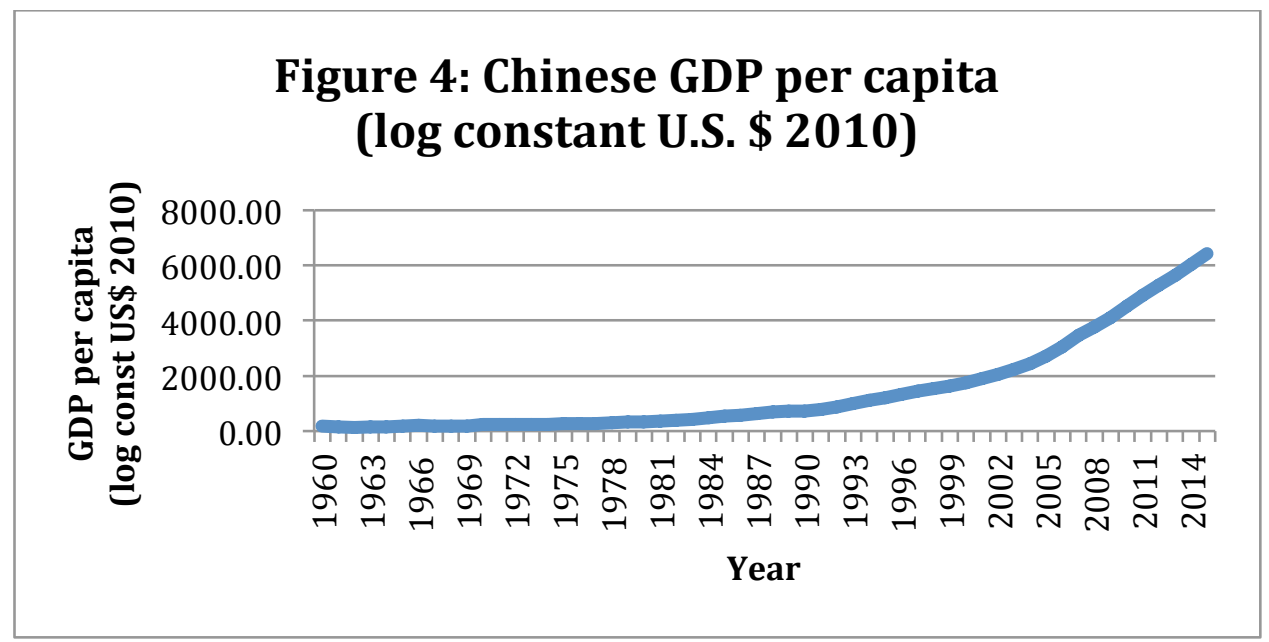

Data Source: The World Bank (2016b)

Figure 4 shows that China has been experiencing rapid growth of GDP per capita since 1970s. Specifically, the growth rate was fast between late 1990s and early 2000s. But in the recentt years the pace of the growth has slowed down. Given that 
China is one of the largest economy of the world, low demand for iron ore could be result of recent slowdown of Chinese economy, leading to lower price of iron ore.

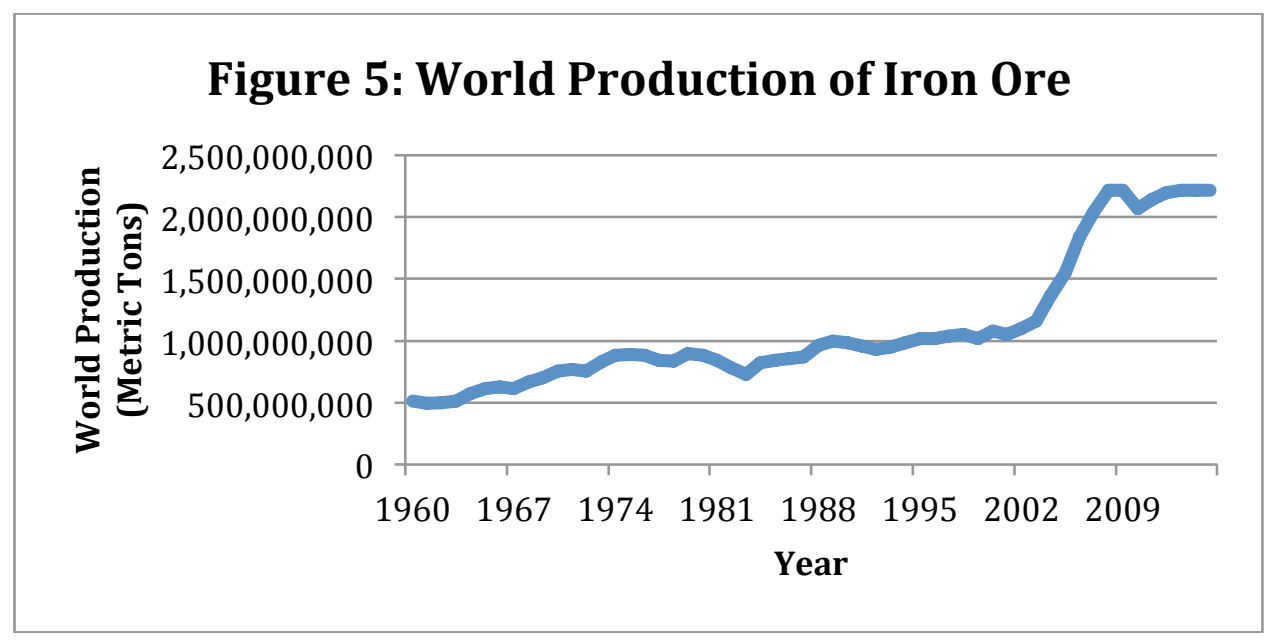

Data Source: Kelly and Matos (2014), U.S. Geological Survey

Figure 5 shows that world production of iron ore has been rising over the years. Compared to late 1990s world almost doubled its iron ore production in 2016. Higher world production could be translated as greater supply of iron ore and thereby declining price of iron ore.

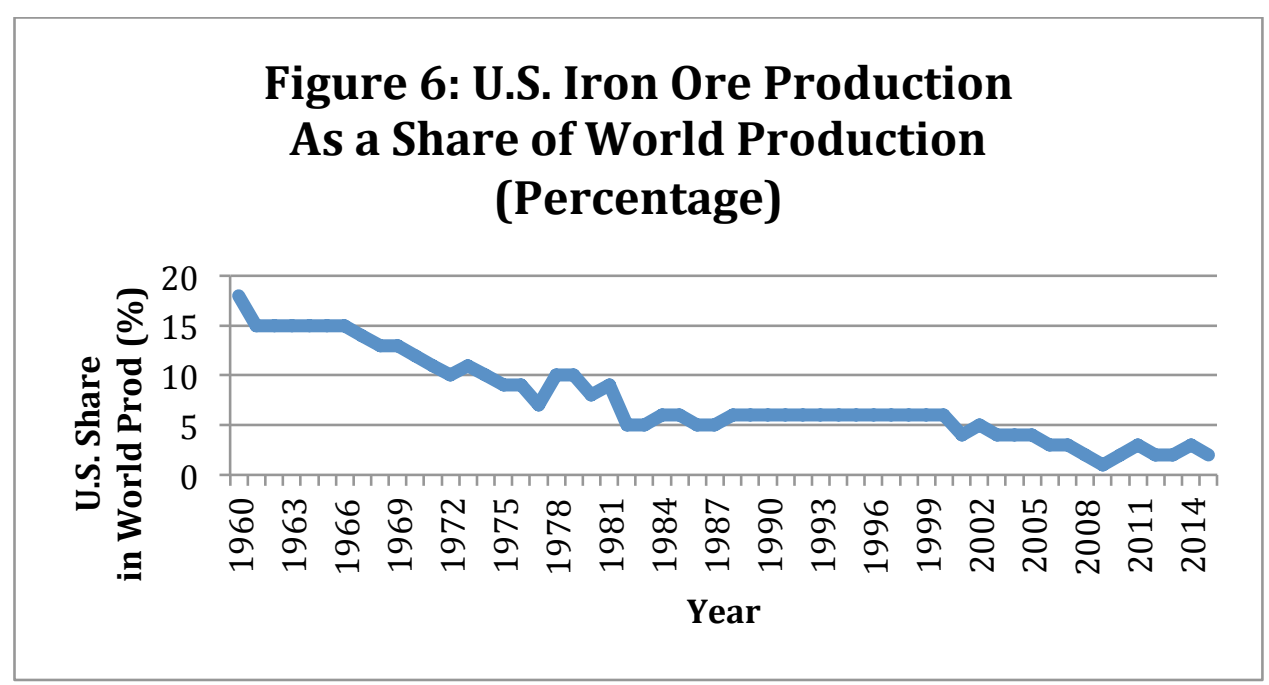

Data Source: Kelly and Matos (2014), U.S. Geological Survey

According to U.S. Geological Survey the share of U.S. iron ore production as percentage of world production has declined significantly in the last few decades. Figure 6 shows that since 2010 U.S. produced only 2-3\% of the world iron ore - an insignificant amount. Weidmann, Schandl, \& Moran (2014) reported similar evidence stating five top iron ore producers of the world are Australia, China, Brazil, India, and Guinea. Also, according to Ng (January 12, 2016) Australia and Brazil have been successful in capturing a larger share of China's iron ore market. 


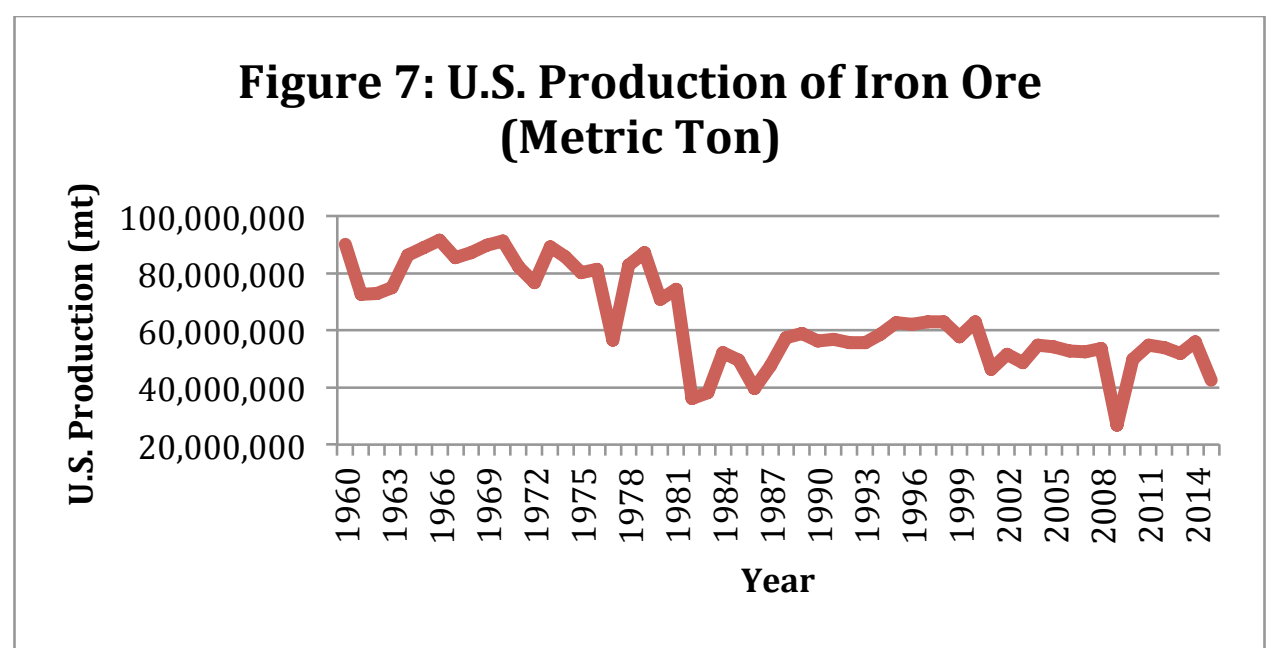

Data Source: Kelly and Matos (2014), U.S. Geological Survey

The declining importance of U.S. iron ore is also evident in falling production and exports of iron ore by the U.S. in recent years. Figure 7 depicts that the U.S iron ore production dropped by around half during late 1970s and early 1980s comapred to the 1960 s.

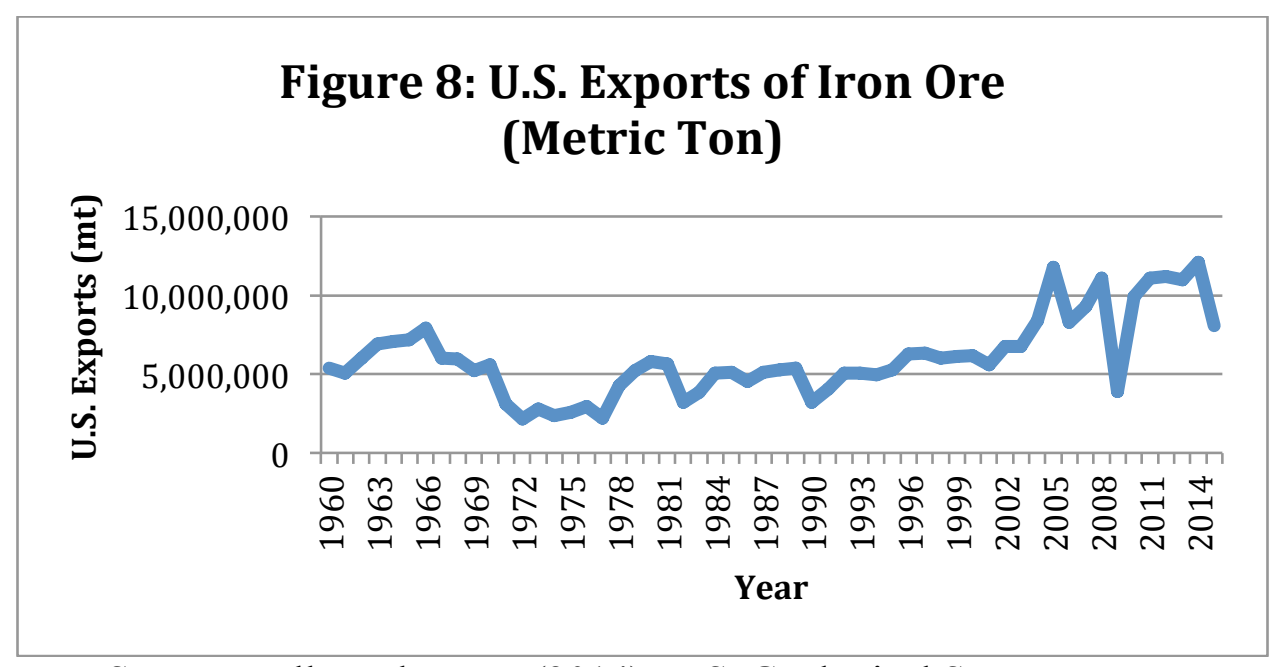

Data Source: Kelly and Matos (2014), U.S. Geological Survey

Figure 8 shows that exports of U.S iron ore in the years since 2013 have been falling. 


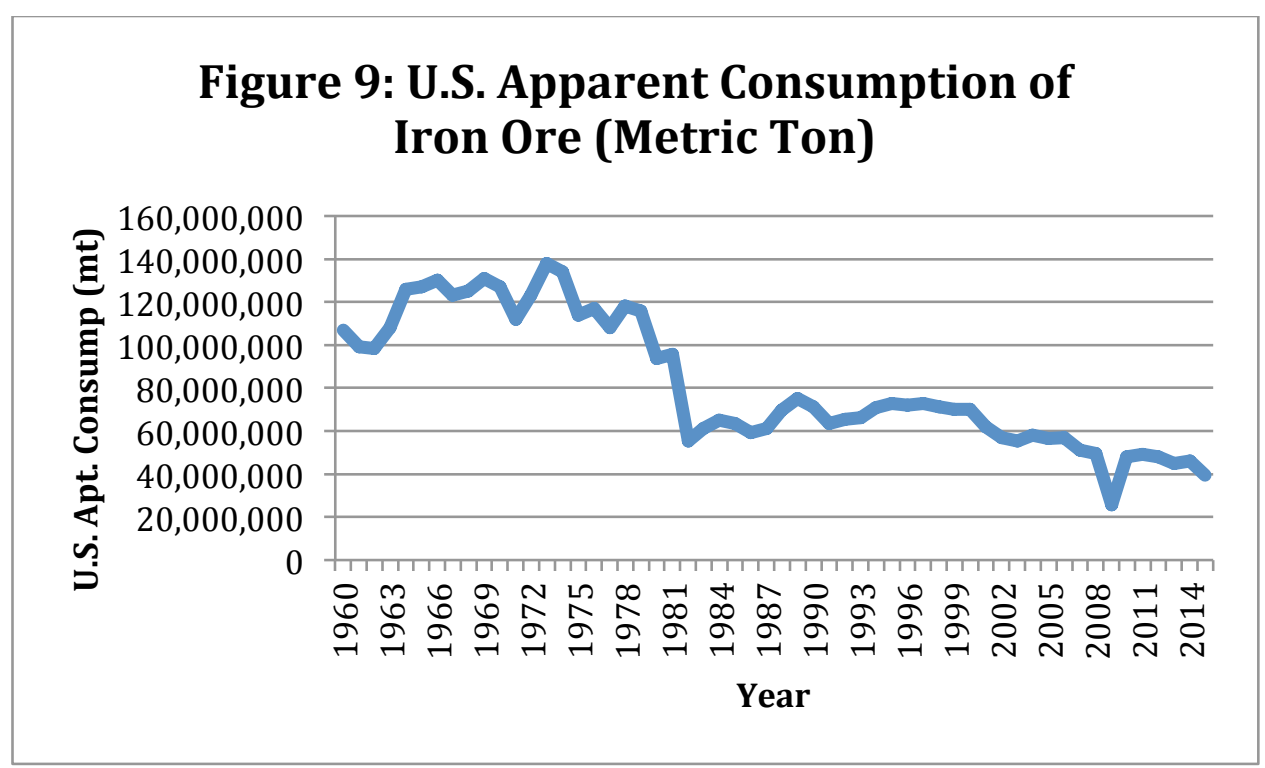

Data Source: Kelly and Matos (2014), U.S. Geological Survey

Demand for U.S. iron ore comes not only from foreign coutries but also from domestic producers. Figure 9 shows U.S. apparent consumption of iron ore. By definition:

\section{APPARENT CONSUMPTION $=$ PRODUCTION + IMPORTS - EXPORTS \pm STOCK CHANGES}

The U.S. apparent consumption of iron ore has been steadily declining in recent decades. Also, in recent years U.S. imports of iron ore decreased by more than half compared to last 2 decades. This low consumption translates to low domestic demand of U.S. iron ore.

Analysis of data reveals the following scenario. One one hand, rising world production of iron ore and on another hand, low Chinese (foreign) and U.S. (domestic) demand for iron ore could have played important role in explaining low wages and employment of U.S. iron ore mining.

\section{Conclusion}

In recent years the regional economy of northern Minnesota has been struggling as some mines were closing and laying off workers. This fact not only hurts mining sector but other businesses who have some connectons with mining. This research investigated to find out whether Chinese economic slowdown had any impact on U.S. mining and therby on regional mining layoffs. Analysis of recent news articles, expert interviews, and relevant data show that to some degree slowdown of Chinese economy is a factor in mining layoffs. Also, Chinese steel dumping affected the U.S. steel industry, as the U.S. price was higher than that of its competitors, namely 
China. However, it should be noted that resource based economy is very sensitive to global demand and supply of mineral resources. Some findings imply that the regional layoffs are part of a natural boom and bust cycle. Further, rising world production of iron ore and low Chinese as well as U.S. domestic demand for iron ore could be utilized in explaining low prices of iron ore leading to low wages and employment of U.S. iron ore mining.

This study is limited by the availability of and accessability to data of Chinese economy and its iron ore production, consumption, and import. In future, having data on Chinese iron ore would improve the paper greatly. 


\section{Appendix}

\section{Interview Questions:}

1. What's your overview of the local mining industry?

2. How are current employment/job situation and layoffs in local mining industries?

3. What do you think the reasons are for the layoffs?

4. If Chinese economy has anything to do with the current situation of the local mining industry?

5. What do you think should be done to improve current condition of local mining industry? Or, what do you think should be done to resolve layoffs of mining industry? 


\section{References}

Davis, D. (2016, February 22). Obama Pledges to Fight China Steel Dumping. Retrieved from http://www.duluthnewstribune.com/business/mining/3953714-obamapledges-fight-china-steel-dumping

Deller, S., \& Schreiber, A. (2012). Mining and Community Economic Growth. The Review of Regional Studies, 42(2), 121-141.

Jefferson, G. H., Hu, A. G., Jian, S., Barry, B. P., \& Gustav, R. (2006). The Sources and Sustainability of China's Economic Growth/Comments and Discussion. Brookings Papers on Economic Activity, (2), 1-60.

Johnson, Kelsey. (June 2016). Expert Interview. Conducted by the author.

Kelly, T. D., \& Matos, G. R. (2014). Historical Statistics for Mineral and Material Commodities in the United States. U.S. Geological Survey.

Kraker, D. (2016, April 11). Mine Layoffs Bring New Calls to Remake Iron Range Economy, But Into What? Retrieved from http://www.mprnews.org/story/2016/04/11/iron-range-economy-layoffsdiversification

Krueger, A. (2016, June 9). Cliffs Says United Taconite Restart Has Been Moved Up

Two Months. Retrieved from

http://www.duluthnewstribune.com/business/mining/4051022-cliffs-saysunited-taconite-restart-has-been-moved-two-months

Minnesota Department of Natural Resources (MN DNR). (2016). Mining in

Minnesota. Retrieved from http://www.dnr.state.mn.us/education/geology/digging/mining.html Myers, John. (2016, January 8). Essar Lays off Some Local Employees. Retrieved from

http://www.duluthnewstribune.com/business/mining/3920397-essar-layssome-local-employees

Myers, J. (2016, May 18). US Approves Tariffs on More Foreign Steel. Retrieved from http://www.duluthnewstribune.com/business/mining/4035883-usapproves-tariffs-more-foreign-steel

Myers, J. (2016, July 8). Essar Steel Minnesota Files for Bankruptcy as Dayton Pulls Mineral Leases. Retrieved from http://www.duluthnewstribune.com/business/mining/4070252-essar-steelminnesota-files-bankruptcy-dayton-pulls-mineral-leases

Ng, J. (2016, January 12). China's Iron Ore Imports Surge to Record as Prices Hammered. Retrieved from http://www.bloomberg.com/news/articles/2016-01-13/china-iron-oreimports-jump-to-record-in-december-as-price-sinks

Ongaro, Frank. (June 2016). Expert Interview. Conducted by the author.

The World Bank. (2016a). World Bank Commodity Price Data (The Pink Sheet). The World Bank. (2016b). GDP per capita (constant 2010 US\$). 
Tovey, A. (2016, May 18). America Slaps 522pc Trade Duty on Imports of Subsidized Chinese Steel. Retrieved from http://www.telegraph.co.uk/business/2016/05/18/america-slaps-522pctrade-duty-on-imports-of-subsidised-chinese/

U.S. Bureau of Labor Statistics. (2016). Quarterly Census of Employment and Wages. NAICS 21221 Iron Ore Mining U.S. Total.

United States International Trade Commission. (2016, June 22). Cold-Rolled Steel Flat Products from China and Japan Injure U.S. Industry, Says USITC. Retrieved from http://blog.apastyle.org/apastyle/2010/09/how-to-cite-apress-release-in-apa-style.html

Wang, R., Cheng, J., Zhu, Y., \& Xiong, W. (2016). Research on Diversity of Mineral Resources Carrying Capacity in Chinese Mining Cities. Resources Policy, 47, 108-114.

Weidmann, T. O., Schandl, H., \& Moran, D. (2014, June 26). The Footprint of Using Metals: New Metrics of Consumption and Productivity. Environmental Economics and Policy Studies, 17(3), 369-388.

Zhu, X. (2012). Understanding China's Growth. Journal of Economic Perspectives, 26(4), 103-124. 